\title{
Work-Family Practices and Complexity of Their Usage: A Discourse Analysis Towards Socially Responsible Human Resource Management
}

\author{
Suvi Heikkinen ${ }^{1} \cdot$ Anna-Maija Lämsä ${ }^{1} \cdot$ Charlotta Niemistö $^{2}$
}

Received: 1 April 2019 / Accepted: 5 February 2020 / Published online: 14 February 2020

(C) The Author(s) 2020

\begin{abstract}
The question of work-family practices commonly arises in both theory and daily practice as a matter of responsibility in today's organisations. More information is needed about them for socially responsible human resource management (SRHRM). In this article our interest is in how work-family practices, serve as an important element of SR-HRM, constructed as (un)helpful for employees' work-family integration, are realised in organisational life. We investigate the discursive ways in which members of two different organisations working at different organisational levels construct the issue in the Finnish context. Three discourses were interpreted: (1) a discourse of compliance with external pressure, (2) a discourse of negotiation and (3) a discourse of individual flexibility. Discursive constructions of work-family practices make visible the complex interconnectedness of individuals and organisations with the environment in which they operate. Many organisational efforts to create positive work-family practices can, in fact, lead to failure to make these practices either available or usable, and they may result in the unjust treatment of organisation members. Creating sustainable work-family practices is a complex challenge for which SR-HRM must work out a solution.
\end{abstract}

Keywords Work-family practices · Socially responsible human resource management · Discourse analysis · Work-family integration $\cdot$ Qualitative research

\section{Introduction}

The relationship between corporate social responsibility (CSR) and human resource management (HRM) has increasingly garnered scholarly attention during the past 15 years (Ehnert et al. 2014; De Stefano et al. 2018; Macke and Genari 2019), yet there has been a widespread failure to integrate CSR and HRM (Gond et al. 2011). In particular, the lack of integration has been problematic in the context of the interplay between CSR and work-family practices, with scholars raising the question of whether economic growth

Suvi Heikkinen

suvi.s.heikkinen@jyu.fi

Anna-Maija Lämsä

anna-maija.lamsa@jyu.fi

Charlotta Niemistö

charlotta.niemisto@hanken.fi

1 School of Business and Economics, University of Jyväskylä, Jyväskylä, Finland

2 HANKEN School of Economics, Helsinki, Finland and CSR can coexist (Nyberg and Wright 2013; Macke and Genari 2019). Business ethics debates on the interplay between HRM and work-family practices have mainly developed in isolation from one another rather than within an integrated HRM/sustainability framework (Jamali et al. 2015; Nie et al. 2018; De Stefano et al. 2018).

Here, we adopt a socially responsible human resource management (SR-HRM) approach to investigate work-family practices within organisations. SR-HRM means not only understanding employees as having an instrumental value to the organisation but also aiming to care for and fulfil employees' personal and social expectations and needs, one of which is the need to integrate work and family to support their wellbeing and satisfaction in life (Burke 2009; Beauregard and Henry 2009; Guerci et al. 2015; Shen and Benson 2016; Zhang and Tu 2016; Nie et al. 2018). SRHRM for work-family practices is important for sustainable working life, societal outcomes and quality of life in general, and it is considered a sign of socially responsible and ethical behaviour on the part of the employer (Hobson 2011; Guerci et al. 2015; Shen and Benson 2016; Voegtlin and Greenwood 2016). 
The urge to respond to the challenges of employees' work-family integration has resulted in organisations establishing different types of work-family programmes and practices as part of their HRM (Butts et al. 2013; Voegtlin and Greenwood 2016). These programmes and practices (e.g., flexitime, teleworking, leave policies, childcare services) are geared to enhance organisational support for work and family as well as personal life in general (Kossek et al. 2010; Putnam et al. 2014). Organisational efforts to facilitate work-family integration are full of tensions that are not resolved merely by announcing and offering formal programmes and practices. In organisational life employees may often face an agency gap when seeking to make use of the programmes and practices, due to the lack of a supportive supervisor or organisational culture, or even stigmatisation (Kirby and Krone 2002; Mescher et al. 2010; Putnam et al. 2014; Lewis et al. 2017; Bourdeau et al. 2019).

In this paper, we are interested in how (un)supportive organisational practices in the workplace, constructed as (un)helpful for employees' work-family integration, are realised in organisational life. Our focus is particularly on work-family practices that may or may not be based on formal work-family policies and programmes. Work-family integration here refers to the interdependencies of the work domain and the family domain in an employee's life. Work-family practices are meant to be a means of supporting organisational members' possibilities of successfully integrating work and family (Greenhaus and Kossek 2014). Specifically, drawing on discourse analysis we investigate the boundary between work and family within an organisation and why it exists, the extent to which work-family practices are construed as being available, and how the discourses function and the implications they have for SRHRM. We also seek to make visible the kind of positions of power and responsibility that the discourses produce for different actors with respect to creating the capabilities and constraints that allow for work-family practices in organisational life (Sterponi 2003). Discourses on work-family practices can be seen as the rationale behind, for example, organisation members' various claims of fair or unfair processes, and the outcomes of work-family integration (Lewis et al. 2017). Our contribution here is to offer insights into how work-family practices and SR-HRM may result in ethical challenges, and make them more visible and ultimately more manageable.

Studying work-family practices from the viewpoint of SR-HRM extends previous research in the following ways. Although work-family practices can act as a medium to support employees' work-family integration and advance their wellbeing (Hobson 2011), when these practices are offered, organisations may, albeit unintentionally, create conditions which encourage unequal or preferential treatment in their use and ultimately cause ethical challenges (Kirby and Krone 2002; Mescher et al. 2010; Russo et al. 2015; Li et al. 2017). In small- and medium-sized organisations there are evidently quite often situations for which there are no formally established work-family practices (Perry-Smith and Blum 2000), and informal practices can ultimately lead to employees having a sense of unpredictability and lack of control. This creates a sense of injustice, particularly when people feel that specific goals, for instance the possibility of integrating work and family, are critical to them (Cropanzano et al. 2001).

It has also been suggested that organisation members might not want to use the practices that are available because they do not want to transfer their workload to others. Those without small children, for example, might feel burdened by the transferred workload (Clark et al. 2017). This may in turn also lead to a sense of stigmatisation for those who use the practices (Bourdeau et al. 2019). Previous research suggests too that access to work-family practices may be limited to high performers (Wharton et al. 2008). If the workload and life situations of all employees on various organisational levels are not taken into account fairly and transparently, colleagues may be even less keen to cooperate and be flexible (Kirby and Krone 2002; Clark et al. 2017).

Bochantin and Cowan (2016) allege that research into work and family has been dominated by a functionalist paradigm and that we need other methodological perspectives that challenge the basic assumptions and expectations of work-family research and contrast with this positivistic understanding (Shockley et al. 2017). We follow this suggestion and have adopted discourse analysis as the methodological choice for this study. We draw on a critically oriented discourse analytic approach, which emphasises the content of the topic and its broader social reality rather than studying linguistic features of texts as happens in, for example, conversational analysis (Phillips and Hardy 2002; Wood and Kroger 2000). In line with our approach, we focus on an important social issue-the relationship between work and family - and question ideas around it that are often taken as self-evident (Phillips and Hardy 2002). Typically, the relationship has been assumed to be either conflicting or enriching (Greenhaus and Powell 2006). A more nuanced view is needed.

One strength of the adopted approach is that it allows us to uncover the social reality of SR-HRM concerning work-family practices, and explore and understand the complexity of the phenomenon and how people in organisational life make sense of this complexity. The approach reveals how power is positioned in the articulation of the topic, which always also involves the assumption of moral responsibility (Fairclough 1992; Phillips and Hardy 2002; Sterponi 2003; Phillips et al. 2004). It is important to study discourses as they really are, not only as describing and constructing social reality, but also as acting as a powerful force 
in organisational life to serve particular ends (Phillips and Hardy 2002). If we can point out how one can talk acceptably about work-family practices and perform them in practice, we can identify work-family practices that are limited, enabled and controlled in organisational life and the people who are considered responsible for them (Fairclough 1992; Hall 2001). Discourse analysis does not offer any absolute truth on the subject (Fairclough 1992), but it helps us to understand various ideas and challenges linked to work-family practices in a specific context and enables us to consider what these aspects mean from the viewpoint of SR-HRM.

\section{The Links Between CSR, SR-HRM and Work- Family Practices}

The rise of corporate social responsibility (CSR) has had significant implications for HRM practices, such as employee representation, social involvement in the form of employee volunteering, the setting of minimum labour standards and the role of HRM in implementing CSR practices (Preuss et al. 2009). The interest in CSR has also meant that there has been more discussion and emphasis on ethical aspects of the work-family relationship (e.g., Jamali et al. 2015; Nie et al. 2018). Gond et al. (2011) identify various ways in which HRM can relate to CSR work, with different degrees of integration between them. The first mode is that CSR is managed as one part of the key HRM roles or can emerge as such, which facilitates the full exploitation of the synergies between the two. As pointed out by Guerci and Pedrini (2014), when there is consensus among HRM and CSR managers regarding reciprocal roles in responsibility, the organisation moves more quickly. In their model, the second mode is that HRM is a shared function between CSR and other departments, or it emerges from a department other than HRM, leaving space for internal power balances that shape the extent to which HRM is actively involved in responsibility work. In these cases, HRM mainly takes on the social aspect of CSR, and the coordination with other departments is highly contingent upon internal power relationships. The third mode is that HRM implements actions that support CSR with respect to employees and their needs, and CSR is viewed as an independent function in its own right. Internal power balances also shape the extent to which HRM is actively involved within this relationship.

The role of HRM in developing sustainable work and HRM systems and the role of HRM in supporting ethics and responsibility in business organisations are topics that have been recently raised (Guerci et al. 2015; Jamali et al. 2015; Turner et al. 2019). However, work-family practices as a question of SR-HRM and the perceived fairness related to organisational work-family practices still lack research attention (Bourdeau et al. 2019). CSR initiatives that are often controversial and ambiguous by nature highlight such social issues as concerns about the family life of employees in the organisation (Mele 1989; Turner et al. 2019). For example, a claim has been made that in countries with lowbirth rates, organisations must become more family friendly so that younger employees will have the courage to start a family (Schleutker 2013).

The origin and ideology behind work-family practices is a mechanism that has an effect on the social responsibility underpinning work-family practices. Drawing on business models as the rationale for work and family integration, Peper et al. (2014) concluded that organisations and, specifically, their management could consider work-family practices from two perspectives. On the one hand, organisations may see them as disrupting the normal pattern of work and therefore will be unsupportive of requests to use them. On the other hand, recognising that they are dependent on their employees' input, organisations may be supportive and see the value of the practices in motivating and retaining employees who are important for the organisation's output. In organisations where employees' knowledge and skills are particularly high, and critical to the organisation's success, the dependency argument may be dominant.

In addition to the business model argument, the moralethical argument has been put forward as a means of legitimating practices that integrate work and family (Hobson and Fahlén 2009; Hobson 2011). Support for work-family integration is seen not as having an instrumental value in improving employee output in the short term, but as an end in itself, for the sake of employees' quality of life. Studies by Barley et al. (2011) and Ross et al. (2017) show the complexity of the relationship between work and family in practice: on the one hand, the increasing volume of e-mails and other technologically enabled communications (e.g. smartphones, laptops) widely contributes to employees' sense of flexibility and control, but on the other hand this type of constant accessibility is also a source of stress to them. Barley et al. (2011) found that the longer people spent on their e-mail, the greater was their sense of being overloaded, and the more e-mail they processed, the greater their perceived ability to cope.

HRM, through its relationships in all levels of the organisation, plays a key role in promoting positive behaviour, in creating an engaged workforce and in creating an environment where different aspects of an employee's life cycle are taken into consideration. Previous research from the 1990s onwards (e.g., Goodstein 1994; Thompson et al. 1999; Allen 2001; Behson 2005; Davis and Kalleberg 2006; Andreassi and Thompson 2008; Zuba and Schneider 2013; Bagger and Li 2014) has already well documented the role of HRM in creating an organisational culture in which themes such as time and workload demands are given sufficient consideration, as well as the career consequences of taking advantage 
of work-family practices, and the effects of managerial support on the availability and usage of work-family practices. With regard to time demands, it can be debated whether work-family practices such as flexitime and teleworking reflect employees' perception that in order to be an ideal worker, one ought to work long hours and put work before family (Andreassi and Thompson 2008). The 'ideal worker' norm is often juxtaposed with the use of work-family practices; failure to meet the norm may have negative consequences, such as the need for presenteeism and overachieving, stigmatisation, unequal distribution of work load or career obstacles (Bourdeau et al. 2019). The role of HRM is to avoid the mixed messages that are often sent in the organisation about work-family concerns, and ensure that supervisors and top management support work-family integration or the use of work-family practices (Kirby and Krone 2002; Kossek et al. 2010; Russo et al. 2015; Zhang and Tu 2016; Clark et al. 2017).

In sum, we claim that although work-family practices are a common topic in both theory and the daily practices of today's organisations (Butts et al. 2013; Putnam et al. 2014), we still need more information about them. They are complex, ambiguous and culturally embedded issues that continually arise in people's daily lives and as their rationale for social actions. Research needs to examine the complexity involved in giving fair treatment to everyone, and in the use of power when making work-family integration available on equal terms to all members of the organisation.

\section{Societal Context of the Study}

The socio-cultural context sets up different pressures on organisations to provide work-family practices (Pache and Santos 2010). The context under scrutiny here is Finland, a Nordic welfare state. In Finland, family is ranked high in the value system and, in line with the other Nordic countries, the legislative framework for family leave, public day care and flexible working time is relatively well developed (Pietiläinen 2013). Family leave is relatively generously compensated, and day-care costs are subsidised, both from the national tax revenues. Finland has free education all the way to university level. This means that people from very different socio-economic backgrounds can have the education they prefer. Anyone can have a university education, which is typically required for work in knowledge- intensive organisations. Finnish women have the third highest level of education among OECD countries, and they outpace Finnish men in education (Statistic Finland 2018).

Legally, Finland has a relatively high level of gender equality. This is a sign that women are valued as part of the workforce and both men and women are able to pursue a full-time career (Hantrias and Letabiler 2014; Global
Gender Gap Report 2017). The Finnish population is aging very rapidly, and it is estimated that the number of young people will fall significantly in the next couple of decades due to the drop in the birth rate (Statistics Finland 2018). This challenges employing organisations to develop more family-friendly practices than before.

Although there is an extensive system of public childcare to encourage full-time work for both spouses, Finnish women still carry the main responsibility for domestic work and childcare (Heikkinen et al. 2014; Heikkinen and Lämsä 2017). Despite the legal opportunities for both parents to take parental leave, it is used almost exclusively by mothers; in fact, Finnish men rank low among their Nordic counterparts in their interest in using parental leave (Pietiläinen 2013). This has had serious consequences for Finnish organisations, allowing them to remain relatively passive in developing organisation-level policies and different types of arrangements to make combining work and family life possible for all employees. However, more recently, organisations have shown increased interest in work-family integration, due at least in part to their increasing interest in and pressure for CSR (Shen and Benson 2016).

\section{Methods}

The discourse analysis employed here, with its focus on the ordinary, everyday use of linguistic terms as well as the context in which the terms are used, offers a useful method for studying the field of work and family (Moi 1999). Discourse is socially constructive as well as socially conditioned; it constitutes situations, objects of knowledge and the relationships between people and groups of people (Wodak 2011, p. 37). By discourse, we refer to a relatively coherent system of meanings that are constructed through language use (Phillips and Hardy 2002; Phillips and Malhotra 2008). In other words, we explore the discourses that bring work-family practices discursively into being (Parker 1992, p. 5).

To provide the data for this study, we used purposeful sampling, which is a widely justified method of qualitative research (Patton 2002). With this method, information-rich cases are targeted from the viewpoint of the phenomenon of interest (ibid.). We selected two business organisations that were willing and motivated to participate in the study, a business law company and an IT company. Two criteria were particularly important in choosing these organisations. Firstly, the organisations needed to be knowledge-intensive organisations with employees who are skilled professionals. This was because many work organisations in Finland (and elsewhere) have been changing and are expected to change in the future in such a way that employees now need to be experts committed to their work projects rather than just people who clock on for a specific number of hours. 
Employees need to continually learn new knowledge and skills as a normal part of their lives and also increasingly make use of new technology (Pyöriä 2012). Since employees' work in such organisations is not fixed to specific hours, it can be done in different places, including the home; this means that the boundary between work and family life is increasingly blurred and difficult to manage. The work done in the organisations studied here can be considered to represent not only contemporary, but also future, trends in working life, and in this sense, these selected organisations can be considered homogenous (Patton 2002).

Secondly, to provide multiple viewpoints (Patton 2002) on the topic, the selected organisations needed to differ in their work-family policies. This is because the policies can affect the amount of support employers are willing to give to employees' opportunities to integrate work and family. Formal work-family policy was more developed in the law company than in the IT company. The law company can be described as a relatively advanced, even a family-friendly organisation, while in the IT company little attention has been formally paid to family friendliness.

Our empirical data consist of interview data from a total of 22 interviews. The participants were balanced fairly evenly between men (12) and women (10). The ages of the respondents varied from 29 to 59 years, and most of the respondents reported having children or other care responsibilities in their non-work lives. Only two female managers reported that they were single, with one of them explicitly stating that she had no care responsibilities. In some rare cases, the children were already adults and the participants might have grandchildren. The participants were all professionals working in a more or less 24/7 work environment: some of them worked with clients and colleagues in different time zones, and many others were anyway expected to be almost constantly available. We conducted semistructured, one-to-one interviews with all the participants (Lindloff and Taylor 2002). All the interviews were conducted at the respondents' workplace, in specific rooms in which it was possible to talk to them without interruption. Interviewing the respondents on their work premises gave the researchers a sense of the work environment and everyday organisational life. According to Briggs (2001), field researchers conducting interviews can imagine the social worlds depicted in the content of the responses and create images of, for example, workplace realities. Conducting the interviews at the respondents' place of employment helped ensure a comfortable, trusting situation and an emotional connection between interviewer and interviewee, creating an interpersonal space for articulating individual thoughts, situations and perspectives (see, e.g., Briggs 2001). The respondents and organisations were ensured anonymity, and the number of respondents per organisation was also large enough to ensure that individuals could not be internally recognised within the organisation. This was important, as even if some of the themes in the interviews were more general, more personal themes were discussed, too. The interviews covered the nature of the participants' work and the content of their family life, individual and organisational culture, policies and practices regarding work and family integration, and the prospects of future development of the organisation's operations and more generally in that field. All the interviews were recorded using audiotape and were transcribed verbatim. Each interview lasted from 50 to $90 \mathrm{~min}$. The respondents came from different levels of the organisations, from administrative staff to top management. Detailed information about the research participants can be found in Table 1. Although all the participants were promised anonymity, some of them did not want to reveal all their personal information, and therefore some information is missing in the table.

In our analysis we were interested in both how the respondents' understandings of their realities are constructed and mediated and how power with respect to the ongoingprocesses within the organisations are constructed. In our analysis we used a qualitative analysis software program (NVivo) to support organising and sorting the research data. The use of the program helped us to analyse the large and varied data more systematically and accurately. In order to ensure anonymity, each interviewee was assigned a code number from 1 to 22 . Later on, the numbers were changed to pseudonyms, which are used later in the text and in Table 1 . To respond to the criticism put forward by Beigi and Shirmohammadi (2017) that qualitative work-family research often fails to discuss its data analytics techniques, we proceeded with the data systematically. In the coding phase of the analysis we identified the main themes, or initial discourses, on work-family practices based on recurring patterns in the research data. These themes were (1) perceptions of work-family arrangements, (2) individual ways of combining work and family, (3) inequalities in work-family integration and (4) organisational responses to work and family integration. In the first round, we went through the research data as a whole and read them many times. After that we coded and recoded all the pieces of texts in which the participants talked about the relationship between work and family and arrangements related to it. This was then followed by a phase in which we interpreted the major themes that encompassed talk about work-family integration, and in particular about what kind of mechanisms and arrangements enabled or hindered it, in order to grasp what was actually meant in this research data when work and family practices were discussed.

After this we applied discourse analysis, as suggested by van Dijk (1993), which focuses on dominance and power relations. We analysed the themes as initial discourses in terms of how the respondents talked about making use of 
Table 1 Description of the research participants

\begin{tabular}{|c|c|c|c|c|c|}
\hline Research participant & Gender and age & $\begin{array}{l}\text { Organisational posi- } \\
\text { tion }\end{array}$ & $\begin{array}{l}\text { Work experience } \\
\text { (years) }\end{array}$ & Education & Family \\
\hline Ann & Female, 40 & Customer manager & 19 & $\begin{array}{l}\text { Bachelor of business } \\
\text { administration }\end{array}$ & $\begin{array}{l}\text { Married, school-aged } \\
\text { children }\end{array}$ \\
\hline Barry & Male, 32 & $\begin{array}{l}\text { ICT specialist, team } \\
\text { leader }\end{array}$ & 9 & Automation engineer & $\begin{array}{l}\text { Married, children under } \\
\text { school age }\end{array}$ \\
\hline Cecilia & Female, 34 & Sales assistant & 16 & No information & Married, pregnant \\
\hline Diana & Female, 41 & Specialist in help desk & 20 & $\begin{array}{l}\text { Certificate in data } \\
\text { processing }\end{array}$ & $\begin{array}{l}\text { Married, school-aged } \\
\text { children }\end{array}$ \\
\hline Ethan & Male, 38 & System technician & 14 & Business graduate & $\begin{array}{l}\text { Married, school-aged } \\
\text { children }\end{array}$ \\
\hline Ferris & Male, 37 & ICT specialist & 14 & B.Eng. & $\begin{array}{l}\text { Married, school-aged } \\
\text { children }\end{array}$ \\
\hline Gareth & Male, no information & ICT specialist & 10 & Data network engineer & $\begin{array}{l}\text { Married, school-aged } \\
\text { children }\end{array}$ \\
\hline Henry & Male, 32 & ICT specialist & 10 & B.Eng. & Married, a baby \\
\hline Isabel & Female, 59 & HR manager & 30 & M.A. (Educ.) & Single \\
\hline James & Male, 55 & Chairman of the board & 31 & LLM & Married, adult children \\
\hline Katherine & Female, 38 & Counsel & 16 & LLM & $\begin{array}{l}\text { Married, children under } \\
\text { school age }\end{array}$ \\
\hline Leo & Male, 39 & Specialist partner & 17 & LLM & $\begin{array}{l}\text { Married, children under } \\
\text { school age }\end{array}$ \\
\hline Maggie & Female, 39 & Partner & 15 & LLM & $\begin{array}{l}\text { Married, } 2 \text { small } \\
\text { children }\end{array}$ \\
\hline Neil & Male, 40 & Partner & 14 & LLM & $\begin{array}{l}\text { Married, } 2 \text { small } \\
\text { children }\end{array}$ \\
\hline Olivia & Female, $30+$ & Lawyer & 4 & LLM & Partner, no children \\
\hline Patricia & Female, 50+ & Lawyer & No information & No information & $\begin{array}{l}\text { Married, adult children, } \\
\text { grandchildren }\end{array}$ \\
\hline Quentin & Male, 32 & Lawyer & 6 & LLM & $\begin{array}{l}\text { Married, two small } \\
\text { children }\end{array}$ \\
\hline Rachel & Female, mid 40s & HR director & 12 & M.Econ & $\begin{array}{l}\text { Married, two small } \\
\text { children }\end{array}$ \\
\hline Sally & Female, 32 & Senior associate & 5 & LLM & $\begin{array}{l}\text { Single, no care respon- } \\
\text { sibilities }\end{array}$ \\
\hline Tom & Male, 41 & $\begin{array}{l}\text { Managing partner, } \\
\text { CEO }\end{array}$ & $15+$ & $\mathrm{PhD}$ (law) & $\begin{array}{l}\text { Married, } 3 \text { children } \\
5-12 \text { years }\end{array}$ \\
\hline Umberto & Male, 48 & ICT specialist & 23 & $\begin{array}{l}\text { LLM, information } \\
\text { technology }\end{array}$ & $\begin{array}{l}\text { Married, } 2 \text { children, jun- } \\
\text { ior high/high school }\end{array}$ \\
\hline Vance & Male, 29 & Computer programmer & 7 & No information & $\begin{array}{l}\text { Married, } 2 \text { small } \\
\text { children }\end{array}$ \\
\hline
\end{tabular}

work-family practices as well as how they talked about their negotiations for taking advantage of work-family practices. We also analysed how the respondents talked about the division of power in relevant situations, as well as who were deemed powerful actors in the negotiations. It became evident that the respondents perceived that access to work-family arrangements was restricted by, for example, an unsupportive organisational culture or the supervisor's behaviour, which is in line with previous research. In many cases, an individual's power was quite limited, even if their position within the organisation would have suggested the opposite. On the other hand, we also found elements of a more holistic and more considerate way of perceiving an individual's life situation, in which negotiations occurred on more equal terms. This paradox was intriguing to us and we continued analysing the data along these lines, and emphasising power relations in our analysis. Finally we formed three discourses, which we chose to call (1) discourse of compliance with external pressure, (2) discourse of negotiation and (3) discourse of individual flexibility. These discourses were not always clear-cut; sometimes they co-existed and sometimes they competed with one another. In particular, the discourses of compliance with external pressure and of individual flexibility co-existed with one another, yet they also took place at 
different levels, meso and micro, respectively. The discourse of negotiation was more different from the other discourses. All the discourses were found in both of the organisations studied here. It is important to remember that the discourses were produced by employees who are relatively highly educated and have access to the Finnish welfare system and day care, which makes it possible for parents with children to both have a career. Next, we introduce our results in detail.

\section{Discourse of Compliance to External Pressure}

A common feature in the discourse of compliance to external pressure is the construction of demands that affect organisation members' opportunities to combine their work and family lives. Demands are constructed as external pressure from the surrounding business environment, particularly from customers, and the customs of that branch of business. This results in work and family often being construed as in conflict, and work being prioritised over family. This is not constructed and mediated as a matter of individual choice, instead market forces and business culture are constructed as key elements that regulate and control the boundaries of work and family and ensure that there is no clear boundary segmentation. The following quote highlights the idea of this discourse in an individual employee's work:

I know that many [other employees than me] can't define them [their working hours]; if the supervisor tells them in the middle of the night to do a job before morning, that the deadline is in the morning, then they've got no option.

(Rachel, mid-40s, HR director with two small children)

In this discourse, the talk is rather negative, and power in this discourse is positioned as being exercised by actors outside the company. Responsibility for employees' opportunities to satisfactorily integrate work and family, however, is not construed as being the responsibility of such outsiders. Yet although respondents described outsiders as key controllers of the employees' work-family relationship, outsiders were not constructed as responsible for the negative effects of their demands for work-family integration. This discourse presents HRM as a rather powerless actor whose main social responsibility is to produce formal policy and documentation on employees' work-family practices but who leaves actual responsibility for managing the boundary between work and family in the hands of individual employees themselves (Gond et al. 2011). Gradually, this has become the accepted practice in the organisation. This point is illustrated in the following quote, in which the customer's demands are justified by the harsh competition within the field, leaving no option to the employee but to adjust life to the needs of business:

The competition is pretty harsh in our field; they will find someone else if you won't do it. For example, on Thursday we received comments on a contract, and the client asked if we can have a telecom meeting regarding the comments, and if Friday evening or Saturday is OK. On Friday night I had plans, and I said Saturday would be good. So, we agreed Saturday at a certain time during the day, and I planned my Saturday accordingly. And then, about an hour before, the client sent a message wanting to postpone the meeting to 7PM in the evening, and I had to adapt to it, and said 'sure', even if I had all kinds of summerhouse and family activities, dinner and sauna, but I still had to take the conference call at 7PM on that Saturday night.

(Neil, 40, partner, two young children)

In this discourse, work-family practices are related to flexibility regarding both time and place: work can be done wherever and whenever, as long as employees do what is required of them. Checking e-mails and taking phone calls during the evening are presented as quite acceptable (even expected) and commonly occurring (Barley et al. 2011) in this type of knowledge-intensive organisations. This discourse was more dominant in the law firm than in the IT firm. The interviewees in the law firm commonly talked about the need to be on call round the clock, to re-schedule one's private life according to clients' needs, and to be constantly on call during holidays. At lower levels of the organisational hierarchy, the external pressure was also said to come from supervisors who have been socialised into the culture, while at higher organisational levels the role of clients was more significant. One interviewee from top management made clear that the assumption is an essential part of serving clients:

This is service work where everything revolves around the customers, and our customers pay us handsomely for the help we give them, and we have a lot of international projects and we can have different time zones, which in practice leads to uncomfortable working hours.

(Tom, 41 years; Managing partner and CEO, father of three children)

The talk related to external pressures was integrated into talk about career choices and the extensive workload in both studied organisations. However, especially in the law firm, where moves had been made to develop a formal work-family programme, the offered policies were more a rhetorical device than an actual attempt of facilitating work-family integration in the very competitive environment and given the high-profile careers in the company. This aspect of this discourse arose out of a development project that the 
company had participated in some years earlier, a central part of which had been the aim of increasing organisational support for employees with small children and of retaining female employees in the organisation after having children. The law firm had introduced many formal work-family support policies and even formulated a formal work-family programme in its HRM strategy, and for this reason had the image of a relatively family-friendly employer in the sector. Employees were able to use, for example, nanny services when the children fell ill, a cleaning service and a laundry service, and the company had a playroom for children and maintained contact with employees on family leave. The research participants were well aware of these policies and arrangements, and short family leaves were used by the men. Overall, however, the practices were intended primarily for employees to be able to work more; having one's children at work did not support this, but having a nanny at home did.

In sum, the discourse constructs a rather generally accepted and established acceptance on the part of employees that external pressures on the company meant they should be available whenever or wherever they were needed: external demands are reified and taken for granted in this discourse. This external pressure is also realised in the expectations of what is required to build a successful career (Burke 2009). At the same time, submitting to these external pressures from the business environment makes it difficult for HRM to introduce and develop innovative solutions and show a responsible way of acting not only formally but also in its work-family practices, and ultimately to enhance its SR-HRM. The instrumental business case argument, that is, the organisation's results and performance, is used as the dominant discursive resource to legitimise use of work-family practices (Peper et al. 2014). From the viewpoint of SR-HRM, this discourse positions HRM as a rather powerless adaptor to demands constructed outside the organisation, and leaves the responsibility for successfully organising work-family matters to individual employees, whose possibility of influencing external demands is construed as limited.

\section{Discourse of Negotiation}

A common feature in the discourse of negotiation is that the reconciliation of work and family is construed as fluid and adaptable. Organisation members are said to be actors who have families, and family life is discussed in the workplace (cf. Greenhaus and Kossek 2014). The discourse stresses that it is acceptable to take into consideration the overall life situation of the employee in various work situations. The boundary between work and family is made visible and moving from one life sphere to the other is constructed as effortless. In the discourse this is made clear for example by the fact that people's life situations are made known to other members of the organisation; a managing partner and CEO (a 41-year-old man) mentioned, for example, that there is always baby news on the intranet when someone from the organisation has a baby.

In general, the overall tone of this discourse is positive and the satisfactory integration of work and family is constructed as possible. A key difference in the discourse in relation to the discourse of compliance with external pressures is that here, the life situation of the employee is described as not being regulated by external pressures; instead, priority is given to the organisation's and employees' own steps to find solutions and take responsibility for their welfare and the needs of work-family integration. Both the organisation and individual employees are key enablers in employees' work-family integration; both are responsible for considering the individual's life situation and enabling a positive work-family relationship, and ultimately for enhancing wellbeing and the quality of life. This discourse presents HRM as a powerful actor whose main social responsibility is not only to produce formal programmes and practices, but also to offer informal types of support and create an enabling organisational culture. Responsibility does not therefore depend solely on the individual employee (Gond et al. 2011). The respondents illustrated the supportive environment and negotiations on flexibility in the following ways:

I feel that here [there] is quite a caring atmosphere. Employees are taken good care of, the work ergonomics are good, with electric tables and so on. And you can work remotely every now and then if you need to, so there is flexibility in this regard, too. (Vance, 29 years old, computer programmer with two small children)

I prefer coming to the office at nine, or even a bit later, later than many others, and then I stay on a little later than they do. But this is the kind of field where you don't have any say [laughter]; at times you also have to work when it really wouldn't suit your rhythm. (Olivia, a lawyer in her 30s, no children)

The kind of flexibility demanded here might put additional pressure on parents. Awareness of work-family practices, and also the consequences of flexible practices, is important in organisations, regardless of the situation of individual employees. The exemplary role of management in this matter is key to creating a caring, supportive atmosphere. Diana, a 41-year-old helpdesk specialist with two children at school, said that it is important that the people in top management also pick up their children from kindergarten at the end of the working day at a certain time, and that managers make it clear in the workplace that they also have responsibilities outside work, so that they set others a good example and 
make them feel that the same is possible for them. This is also illustrated in another quotation:

I have not heard bad things, either, in our group, many have... and also the supervisors are starting to have small children. Maybe that changes their own view pretty quickly [laughter]; this will probably change if it hasn't started changing yet... I bet it will change, it might turn into increased interest and family centredness, maybe. (Vance, 29 years old, computer programmer with two small children)

Parenthood was present in this discourse, but it was in the background rather than actively integrated in the talk. In both companies, there were many new fathers, and the research data showed that most of them had used the father's legal month-long leave-not more. One of the partners in the law company said that he was an exception to the general rule: he had had longer parental leave with his two children-almost two years. He said that for him it was important both that he had a high position in the organisation and that he had the chance to be a father and to spend time on a hobby about which he is passionate. He was happy to have combined the different roles in his life:

It's been important to me personally that I could combine these different roles [work and family] so well in other words that I'm not only here or for that reason have got on so well that I can do demanding specialist work and I' $m$ in a very good position in the organisation but on top of that I still have the chance to pursue my hobby.

(Leo, 39 years old, specialist partner, children under school age)

In this discourse, although work-family practices were related to various types of individual adjustments and flexibility, it was mentioned that ultimately the extent to which employees could integrate work and family successfully depended a great deal on negotiation and discussion with supervisors and co-workers. Particularly important for access to work-family practices was said to be the negotiation that happens informally, case by case, in an individual's social network in the workplace. In this discourse, the opportunities for using the work-family practices that are officially available are particularly dependent on the quality of the employee's social relationships, especially with their supervisor but also with their peers, as well as her/his position in the organisation's social network. Respondents emphasised that it is easier to reconcile the demands of work and family and negotiate when the person has a positive social and emotional relationship with her/his co-workers and supervisors and they are all very familiar with each other's families and life situations. This type of flexibility seems to enhance the use and development of work-family practices as possibilities for individual adjustment.

The discourse of negotiation, however, reveals some contradictions in the employees' sense of availability and fairness in using the practices, and our analysis shows some contradictions in this discourse. These become apparent in the fragmented structure of the discourse (see Phillips et al. 2004). In this discourse work-family practices, which are constructed as varied and multiple and their availability often negotiable, may cause problems in terms of equality and fair treatment among employees. When the negotiations have been institutionalised as an informal practice and the rules are not visible on all organisational levels, work-family practices can alternate, depending on the employee's social relationships within the organisation. This means that the respondents may consider it also as a source of unfair treatment.

In general, the respondents construed this discourse as empowering: it strengthens understanding of each organisation member's life situation and promotes satisfactory work-family integration. The moral-ethical argument (Peper et al. 2014), meaning the prioritising in the organisation of members' quality of life and wellbeing, is used as the dominant discursive resource to legitimise using the practices for work-family integration. From the viewpoint of SR-HRM, the discourse positions HRM as an active and powerful enabler of work-family practices in which various types of life situations are not only taken into consideration but also understood as empowering, and creating new kinds of work-family practices. The discourse enables both the use and development of work-family practices at the workplace and potentially helps diversify these practices. At the same time it poses a challenge for SR-HRM due to the fact that the individual's social relationships and position within the organisation's social network are constructed as an important gate-keeper in enabling or controlling how easy it is for the employee to use work-family practices in reality. This tends to cause the feeling that treatment is unequal, which poses a challenge for SR-HRM.

\section{Discourse of Individual Flexibility}

This discourse tests the limits of how far the organisation member is willing and able to go to be a successful professional and employee, and the extent to which she/ he takes deliberate measures to make possible the integration of work and family. In the last of our discourses, the discourse of individual flexibility, flexibility is a one-sided affair-employees' flexibility towards the organisation: they need to arrange and make use of work-family practices to enable more time and space for work. There is pressure on the employee to show that s/he is a loyal colleague and professional and to be successful in her/his career. This can 
lead to the situation that work-family practices are not used at all, as it would make the employee seem uncommitted and unprofessional and might even result in stigmatisation. In their responses, the employees defended their decisions about managing work-family integration as though it was obvious that the individual needs to be flexible for the sake of work, being 'online' for the organisation at all times. Showing dedication to the organisation and being flexible in the face of its demands results in the person being considered a good employee and successful in her/his career. The availability of organisation members can nowadays be controlled by technology-enabled solutions (e.g., software system Lync), as the following quotation highlights:

On the other hand, if we do demand a lot from younger employees and others, well, then you need to also set an example; at least I feel that I can't be the one who leaves first or at least not the one who logs out first, especially now when we have the Lync system, which immediately shows who is logged in and who is not. (Maggie, 39 years old, partner and mother of two small children)

The discourse of individual flexibility is similar to the discourse of compliance to external pressures, but it works at the individual level, and in this discourse the pressures are not external but internal, from within the organisation. This means that the power in this discourse was positioned as lying inside the company. Responsibility for managing employees' satisfactory integration of work and family is subsumed by the idea of the 'ideal worker' and the deliverables of career success (Bourdeau et al. 2019). This discourse presents HRM as having the power to produce formal policy, document employees' level of work-family integration and even provide informal supporting activities, but it ultimately leaves responsibility for taking advantage of such opportunities to individuals who in practice feel trapped by expectations of being an 'ideal worker' for the sake of their employment and career success (Gond et al. 2011). Consequently, then, the challenges and responsibility of managing the boundary between work and family are left to employees themselves and constructed as a need to prioritise work.

In this discourse, the limits and possibilities of using work and family practices are said to be in the hands of the individual, but they are regulated by implicit, invisible organisational demands and the norms of being a successful professional who is always available for work. The discourse functions to emphasise that even though work-family practices are available, the practices are used typically only to enable more time for work. This discourse is rather regulatory in its nature. It places certain restrictions on work and family integration: one's identity as a successful professional, and an implicit expectation of complete devotion to work. It is alleged that if this unexpressed rule is not followed, one's professionalism is questioned.

The questioning of employees' professionalism becomes apparent when discussion about fatherhood is related to the discourse of flexibility and being a successful professional. Respondents mentioned that parenthood, specifically fatherhood, can change the organisation's expectations of (male) professionals. For example, one respondent said that he felt that the organisation expected less of him now that he has small children. He expressed this directly, saying:

I suspect it might be at least partly that they think that because I have a family, they might not demand as much of me, and that is a problem, on the other hand. Because if not so much is demanded of me, I'm not considered as good at doing things, and... I'm a bit, like, I'm a bit left out. (Quentin, 32 years old, lawyer and father of two small children)

In his response, the meaning-making is based on the employee's feeling of being 'mummy tracked' (Benschop and Dooreward 1998), as the respondent is a young father trying to find time for his family despite having a demanding job. He talked about feeling less valuable, put aside, in other words of not being very successful in the workplace. This is rather surprising, as generally the pressure on lawyers in the company is described as very strong, both from outside the organisation, as described in the discourse of external pressure, and from within, as described in the discourse of individual flexibility. Nevertheless, the respondent in question would have expressed a wish or a need for flexibility or less pressure due to his family situation, which would almost suggest the simultaneous presence of the discourse of negotiation.

In this discourse, what is expected from an employee in order to be successful in the organisation seems to be rather clear, but the organisation's attitudes and expectations concerning the employee's family life, e.g. parenthood, are left unresolved. It remains unclear if and how work-family integration fits into the image of a successful professional. This may cause challenges for developing and implementing SR-HRM, especially from the viewpoint of the fair and just treatment of organisational members in terms of work-family integration.

As shown, this discourse partly overlaps with or complements the other two discourses. In this discourse, the business case argument is mixed with the moral-ethical argument to legitimate practices to integrate work and family (Hobson and Fahlén 2009; Hobson 2011). Formally, family friendliness is accepted as part of SR-HRM, so it can be said that in this respect the intentions of the organisation are good. However, if an organisation member takes advantage of the work-family practices, he/she is likely to experience obstacles in his/her career and devaluation as a professional. 
So compared to the second discourse, the discourse of negotiation, the tone of this discourse is negative and problematic as far as the possibility of integrating work and family is concerned. It is argued that despite the organisation's good intentions in public (e.g., Mescher et al. 2010), the whole responsibility is in the hands of individuals whose opportunities are, paradoxically, constrained by the organisation's informal and unexpressed expectations and the norms for what makes a successful professional in the organisation.

\section{Summary and Discussion}

To contribute to a better understanding of work-family practices and SR-HRM, we identified three discourses in the Finnish knowledge-intense organisations: (1) a discourse of compliance with external pressure, (2) a discourse of negotiation and (3) a discourse of individual flexibility. All of them produce opportunities and constraints for work-family practices in organisational life. These discourses show the complexity and double-sided nature of such work-family practices as flexibility, the demands of the field of business, the range of social relationships, and positions of power and responsibility, which were constructed at different organisational levels and positions both different and similar at the same time. Table 2 summarises our key findings and the implications for SR-HRM.

Taken together, the discourse of compliance with external pressure was most clearly present in the law firm, while the discourse of negotiation and the discourse of individual flexibility were present in both of the organisations. This makes it clear that these discourses are simultaneously synchronous and plural. In the first and third discourses (the discourse of compliance with external pressure, and the discourse of individual flexibility), being a successful professional meant flexibility towards the needs of the organisation and its customers, and the assumption that flexibility in the use of work-family practices should happen at the family's expense. This presents the employee with a clear-cut alternative: either be a successful professional or enjoy satisfactory work-family integration. The idea of flexibility, then, usually viewed positively in discussions on work-family integration (Kossek et al. 2010; Putnam et al. 2014), also has a dark side (Bourdeau et al. 2019). Seen from the viewpoint of SR-HRM, showing flexibility, which is a typical feature of the sort of knowledge-intensive workplaces studied here, needs to be mutual: it is a requirement for both parties, the employer as well as the employee.

However, within the discourse of negotiation, the idea of flexibility is partly at odds with the way it is understood in the other discourses: in this discourse, the value of the family is recognised in the organisation, and it is not seen as competing with work. This has the potential to open up opportunities for the development and use of SR-HRMrelated work-family practices. Nevertheless, despite the good intentions, the case-by-case decision-making that the participants reported in this study in connection with the possibility of using this flexibility is constructed as partly unfair and resulting in preferential treatment for some employees. This is an ethical challenge for SR-HRM (Kirby and Krone 2002; Mescher et al. 2010; Russo et al. 2015; Li et al. 2017). As Cropanzano et al. (2001) suggest, it tends to leave employees with a feeling of unpredictability. We think that to overcome this challenge, work-family practices need to be negotiated and agreed upon, not only between supervisor and employee case by case but within the organisation generally with the help of participative processes. This is a prerequisite for open discussion and transparency in SRHRM practices.

Our study indicates that when work-family practices were designed from one viewpoint, that of the business case argument (Peper et al. 2014), their usage was constructed by the organisation members in our study as not actually being available in daily organisational life. This also became apparent in the first and third discourses found in this study (the discourses of compliance to external pressures and of individual flexibility). To deepen understanding of SRHRM, we suggest that the relationship between the ethical argument and the business argument needs to be considered still more in the future. In particular, this study suggests that an ethical viewpoint that stresses the principle of fair treatment needs to be taken into consideration. However, another aspect is on the individual level, taking into consideration the needs of employees with different family backgrounds and life situations and allowing them to pursue various life roles, as they wish (Shen and Benson 2016; Voegtlin and Greenwood 2016; Macke and Genari 2019). SR-HRM must find an appropriate balance between the principles of fairness and individual care. This is something that merits further research in the future.

Our results suggest that even when an organisation is construed as having practices for work-family integration, it is still possible that HRM will try to avoid its responsibility to promote satisfactory work-family integration and ultimately SR-HRM. This can cause an agency gap with respect to who can make use of the practices and how organisation members perceive their availability and usage. Our results also indicate that it is important that HRM not only adapts to the business environment and external pressures but also takes an active role as an agent of change, influencing the business environment in the advancement of innovative and socially responsible work-family practices. In other words, in terms of work-family integration it is important that SRHRM does not just repeat its current ideals and practices and those of its business environment, but recognises its responsibility for actively recreating and renewing them. 


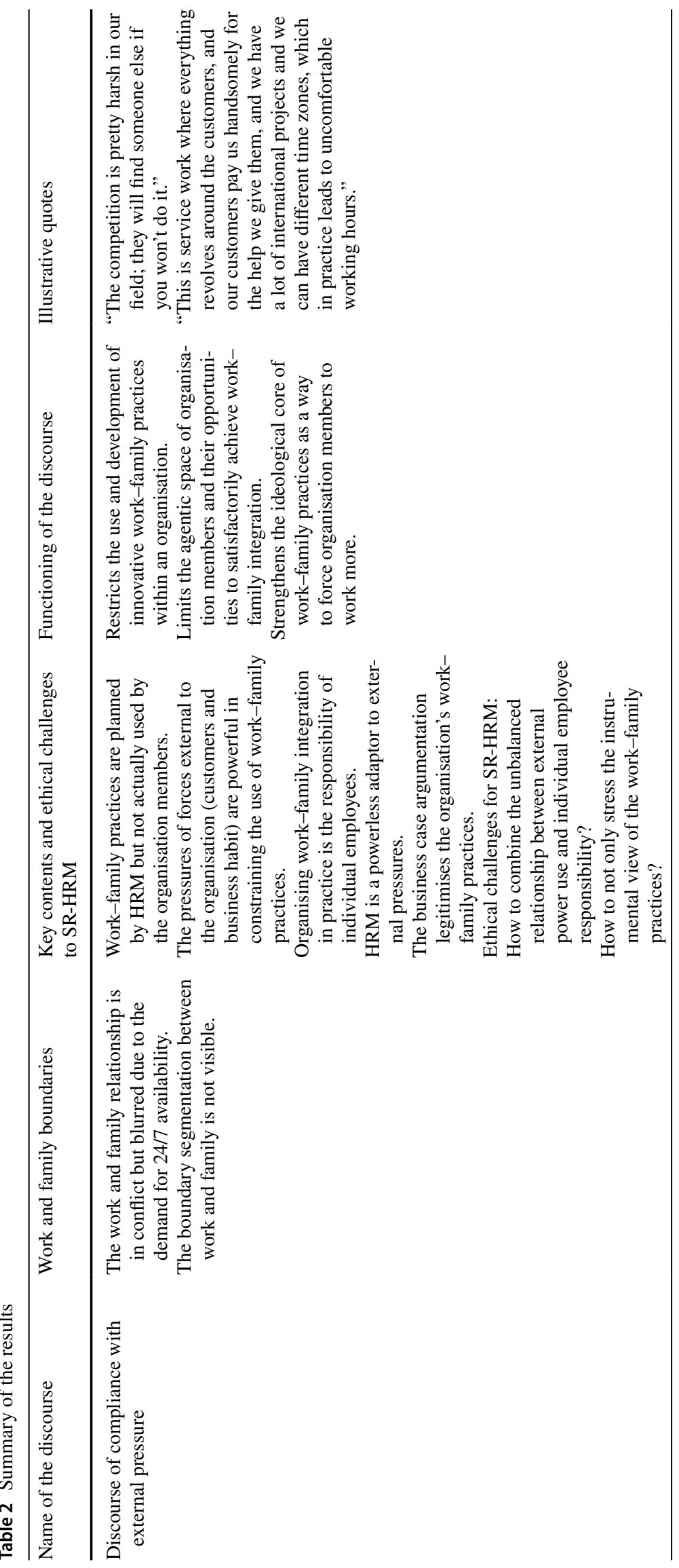




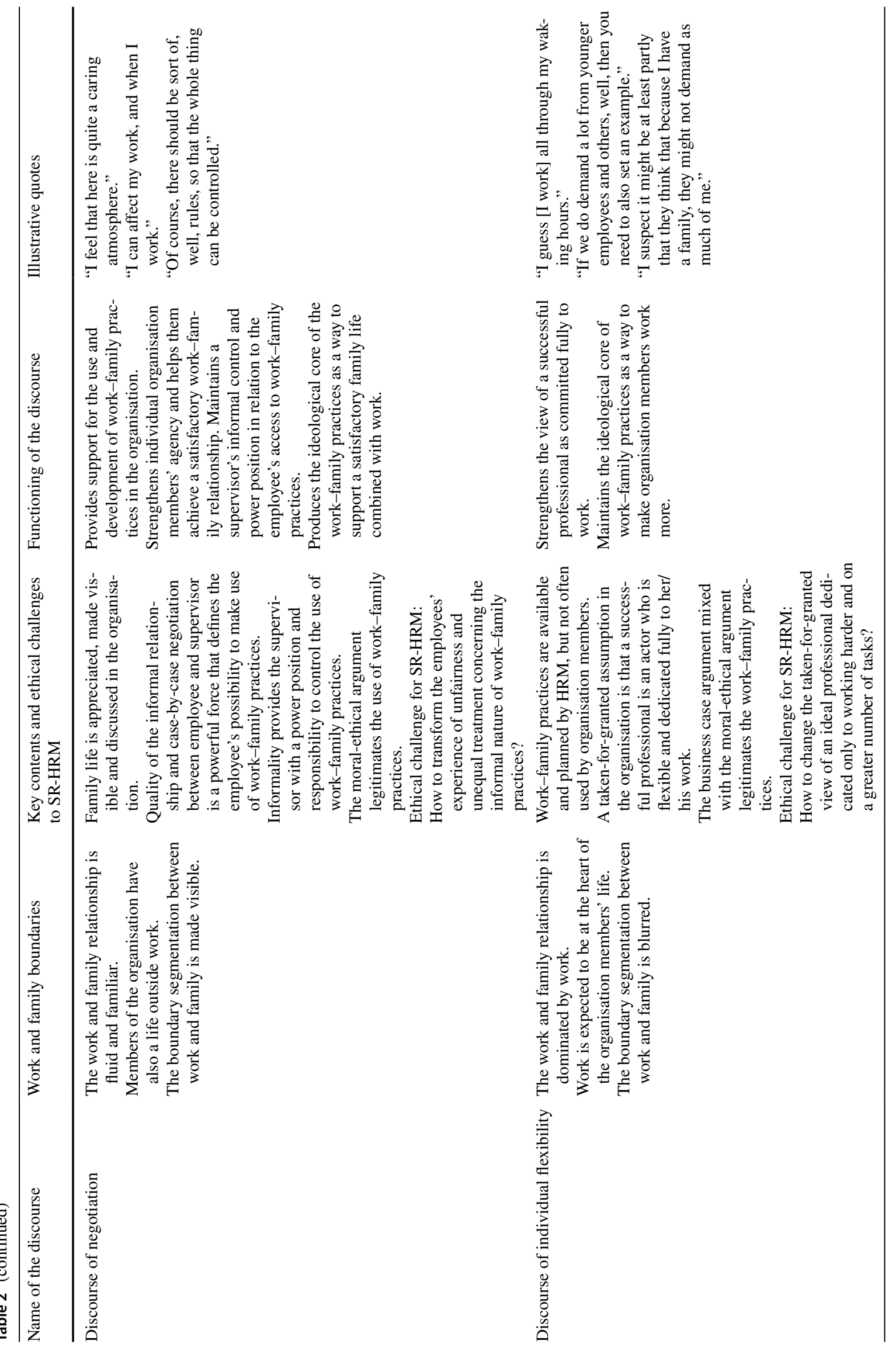


This lends support to the argument of Guerci and Pedrini (2014) and Gond et al. (2011) that when CSR is actively integrated within HRM, especially for employee issues, the social responsibility of the organisation for these issues is likely to develop more quickly than when CSR and HRM are understood as being separate.

Top management and supervisors as well as peers, especially in knowledge-intensive organisations, can have an important exemplary role in promoting satisfactory work-family integration and the proper use of work-family practices. SR-HRM, too, can offer a chance to unpack the traditional juxtaposition of work and family and transform work-family practices and their contradictory nature within organisations (Nyberg and Wright 2013; Russo et al. 2015) and also often beyond organisations. In the future, it would be fruitful to study the (il)legitimation process in relation to the use of work-family practices in an organisation and its business environment and, for example, the types of strategies organisation members use in order not to take advantage of practices that, in the end, are designed to improve the wellbeing of employees with responsibilities outside the organisation (Cleveland et al. 2015; De Stefano et al. 2018).

There are a number of potential implications of all this for practice. As argued above, formal work-family practices are designed to strengthen organisational structural and cultural/relational support for work, family and personal life (Kossek et al. 2010). This paper confirms earlier findings (e.g., Kirby and Krone 2002; Putnam et al. 2014) that there are often major challenges to work-family practices, since even when such practices exist, they are not used or not perceived as accessible or fair in the organisation. When work-family practices are used, it is always difficult for SRHRM to treat all organisation members equally, according to the same principles, while at the same time considering different people's individual needs and expectations in the work-family relationship. More research is called for on the complexities of the issue.

Our results suggest that leaving responsibility for employees' opportunities to successfully integrate work and family solely to society and the social services, as is often the case in Finland (Pietiläinen 2013), or to the individual employee, is too limited. The employing organisations and SR-HRM also have an important role to play here. In practice, the development of formal work-family policies has been problematic in organisations operating in countries such as Finland, where there is strong legal support for work and family integration: the result has been that organisations have remained relatively passive about improving their work-family practices and creating family-friendly cultures. In line with Pietiläinen (2013) and Statistic Finland (2018), the results of this study indicate that organisations and their HRM in Finland can still be relatively passive about enhancing work-family integration. We suggest that besides creating formal work-family practices, organisations (particularly small and mediumsized organisations) should also develop their informal work-family practices, and in particular recognise the importance of individual adjustment and negotiation, which could in the long run foster an organisational culture that could be considered family friendly (Kossek et al. 2014). What must be remembered here is that when informal work-family practices are negotiated, transparency and equality are important parts of SR-HRM (Voegtlin and Greenwood 2016; Jamali et al. 2015).

The implications of this research must be contextualised in the light of its limitations. Only two case organisations were studied, both of which are representative of knowledge-intensive business organisations in a specific societal context. This restricts the generalisability of the results; the results of the study might be different in different organisational settings and in different work contexts. Consequently, we suggest that the topic merits more research in other contexts. For example, work-family arrangements are differently organised in different societies, so it might be worthwhile to do comparative research in the future. However, although our purposeful sampling (Patton 2002) was limited, the discourse analysis approach that we adopted allowed us to produce information-rich knowledge about a relevant social challenge (Fairclough 1992) in contemporary working life, namely the increasingly blurry boundary between work and family and the demands of the 24/7 economy (Kossek and Van Dyne 2008). Even though the links between CSR and HRM in advancing social responsibility to meet this kind of social challenge have been brought to light in this study, we think that, in general, HRM and social responsibility require much more research attention and conceptualisation in the future (De Stefano et al. 2018).

From a methodological point of view, our discourse analysis approach allowed us to make visible some interesting aspects of social responsibility in HRM in relation to work-family practices. Nonetheless, a limitation of the approach is that it focuses on certain ways of talking about and discursively producing the studied phenomenon (Fairclough 1992; Phillips and Hardy 2002; Phillips et al. 2004), and we did not study what people do in actual practice. Seen from this viewpoint, it would be useful to apply an ethnographic approach in future studies. Another limitation of this study is that we did not focus on the gendered nature of the discourses, even though there is a strong suggestion that women use work-family practices much more often than men do and that women in managerial positions in an 
organisation may have a more positive effect on the use of such practices (Wu et al. 2016; Clark et al. 2017; Nie et al. 2018). This could be another valuable angle that could be explored in the future.

\section{Conclusion}

To conclude: following Alvesson and Kärreman (2000) and Putnam and Fairhurst (2001), we found that the discourses surrounding work-family practices revealed a type of talk that problematises the availability and fairness of work-family practices and their use (or lack of it) in organisational life. The study demonstrated the complex interconnectedness of individuals and organisations with the environment in which they are operating and, for example, the logic of competition, the pressures, and the moral considerations that are very much present in many organisations. An organisation's SR-HRM may make a serious effort to reform its policies and find flexible solutions in order to retain key personnel and manage work and family integration better (De Stefano et al. 2018), but at the same time it can work to build and recreate traditional organisational structures that can be a barrier to flexibility and negotiation, so that the practices are neither really available nor usable. This leaves organisation members with a sense of unfairness and inequality.

Acknowledgements Open access funding provided by University of Jyväskylä (JYU). This research was part of the programme Equality in Society (WeAll Project, 292883), supported by strategic research funding from the Academy of Finland (www.weallfinland.fi). We gratefully acknowledge this support.

\section{Compliance with Ethical Standards}

Conflict of interest The authors declare that they have no conflict of interest.

Ethical Approval This article does not contain any studies with human participants performed by any of the authors.

Informed Consent Informed consent was obtained from all individual participants included in the study.

Open Access This article is licensed under a Creative Commons Attribution 4.0 International License, which permits use, sharing, adaptation, distribution and reproduction in any medium or format, as long as you give appropriate credit to the original author(s) and the source, provide a link to the Creative Commons licence, and indicate if changes were made. The images or other third party material in this article are included in the article's Creative Commons licence, unless indicated otherwise in a credit line to the material. If material is not included in the article's Creative Commons licence and your intended use is not permitted by statutory regulation or exceeds the permitted use, you will need to obtain permission directly from the copyright holder. To view a copy of this licence, visit http://creativecommons.org/licenses/by/4.0/.

\section{References}

Allen, T. D. (2001). Family-supportive work environments: The role of organizational perceptions. Journal of Vocational Behavior, $58(3), 414-435$.

Alvesson, M., \& Kärreman, D. (2000). Varieties of discourse: On the study of organizations through discourse analysis. Human Relations, 53(9), 1125-1149.

Andreassi, J. K., \& Thompson, C. A. (2008). Work-family culture: Current research and future directions. In K. Korabik, D. S. Lero, \& D. L. Whitehead (Eds.), Handbook of work-family integration: Research, theory, and best practices. New York: Elsevier.

Bagger, J., \& Li, A. (2014). How does supervisory family support influence employees' attitudes and behaviors? A social exchange perspective. Journal of Management, 40(4), 1123-1150.

Barley, S. R., Meyerson, D. E., \& Grodal, S. (2011). E-mail as a source and symbol of stress. Organization Science, 22(4), 887-906.

Beauregard, T. A., \& Henry, L. C. (2009). Making the link between work-life balance practices and organizational performance. Human Resource Management Review, 19(1), 9-22.

Behson, S. J. (2005). The relative contribution of formal and informal organizational work-family support. Journal of Vocational Behavior, 66(3), 487-500.

Beigi, M., \& Shirmohammadi, M. (2017). Qualitative research on work-family in the management field: A review. Applied Psychology, 66(3), 382-433.

Benschop, Y., \& Doorewaard, H. (1998). Covered by equality: The gender subtext of organizations. Organization Studies, 19(5), 787-805.

Bochantin, J. E., \& Cowan, R. L. (2016). Focusing on emotion and work-family conflict research: An exploration through the paradigms. Journal of Management Inquiry, 25(4), 367-438.

Bourdeau, S., Ollier-Malaterre, A., \& Houlfort, N. (2019). Not all work-life policies are created equal: Career consequences of using enabling versus enclosing work-life policies. Academy of Management Review, 44(1), 172-193.

Briggs, C. (2001). Interviewing at the border of fact and fiction. In J. F. Gubrium \& J. A. Holstein (Eds.), Interviewing, power/knowledge and social inequality (pp. 910-922). London: SAGE.

Burke, R. J. (2009). Working to live or living to work: Should individuals and organizations care? Journal of Business Ethics, 84(2), 167-172.

Butts, M. M., Casper, W. J., \& Yang, T. S. (2013). How important are work-family support policies? A meta-analytic investigation of their effects on employee outcomes. Journal of Applied Psychology, 98(1), 1-25.

Clark, M. A., Rudolph, C. W., Zhdanova, L., Michel, J. S., \& Baltes, B. B. (2017). Organizational support factors and work-family outcomes: Exploring gender differences. Journal of Family Issues, 38(11), 1520-1545.

Cleveland, J. N., Byrne, Z. S., \& Cavanagh, T. M. (2015). The future of HR is RH: Respect for humanity at work. Human Resource Management Review, 25(2), 146-161.

Cropanzano, R., Byrne, Z. S., Bobocel, D. R., \& Rupp, D. E. (2001). Moral virtues, fairness heuristics, social entities, and other denizens of organizational justice. Journal of Vocational Behavior, 58(2), 164-209.

Davis, A. E., \& Kalleberg, A. L. (1990s). Family-friendly organizations? Work and family programs in the 1990s. Work and occupations, 33(2), 191-223.

De Stefano, F., Bagdadli, S., \& Camuffo, A. (2018). The HR role in corporate social responsibility and sustainability: A boundaryshifting literature review. Human Resource Management, 57(2), $549-566$. 
Ehnert, I., Harry, W., \& Zink, K. J. (2014). The future of sustainable HRM. In I. Ehnert, W. Harry, \& K. J. Zink (Eds.), Sustainability and human resource management (pp. 423-442). Berlin: Springer.

Fairclough, N. (1992). Discourse and social change. Cambridge: Polity press.

Global Gender Gap Report. (2017). World economic forum.

Gond, J. P., Igalens, J., Swaen, V., \& El Akremi, A. (2011). The human resources contribution to responsible leadership: An exploration of the CSR-HR interface. In N. M. Pless \& T. Maak (Eds.), Responsible Leadership (pp. 115-132). Dordrecht: Springer.

Goodstein, J. (1994). Institutional pressures and strategic responsiveness: Employer involvement in work-family issues. Academy of Management Journal, 37(2), 350-382.

Greenhaus, J. H., \& Kossek, E. E. (2014). The contemporary career: A work-home perspective. Annual Review Organizational Psychology and Organizational Behavior, 1(1), 361-388.

Greenhaus, J. H., \& Powell, G. N. (2006). When work and family are allies: A theory of work-family enrichment. Academy of Management Review, 31(1), 72-92.

Guerci, M., \& Pedrini, M. (2014). The consensus between Italian HR and sustainability managers on HR management for sustainabilitydriven change-towards a 'strong' HR management system. The International Journal of Human Resource Management, 25(13), 1787-1814.

Guerci, M., Radaelli, G., Siletti, E., Cirella, S., \& Shani, A. R. (2015). The impact of human resource management practices and corporate sustainability on organizational ethical climates: An employee perspective. Journal of Business Ethics, 126(2), 325-342.

Hall, S. (2001). Foucault: Power, knowledge and discourse. In M. Wetherell, S. Taylor, \& S. J. Yates (Eds.), Discourse theory and practice: A reader (pp. 72-81). London: SAGE.

Hantrias, L., \& Letabiler, M. T. (2014). Families and family policies in Europe. London: Routledge.

Heikkinen, S., \& Lämsä, A. M. (2017). Narratives of spousal support for the careers of men in managerial posts. Gender, Work and Organization, 24(2), 171-193.

Heikkinen, S., Lämsä, A. M., \& Hiillos, M. (2014). Narratives by women managers about spousal support for their careers. Scandinavian Journal of Management, 30(1), 27-39.

Hobson, B. (2011). The agency gap in work-life balance: Applying Sen's capabilities framework within European contexts. Social Politics, 18(2), 147-167.

Hobson, B., \& Fahlén, S. (2009). Competing scenarios for European fathers: Applying Sen's capabilities and agency framework to work-family balance. The Annals of the American Academy of Political and Social Science, 624(1), 214-233.

Jamali, D. R., El Dirani, A. M., \& Harwood, I. A. (2015). Exploring human resource management roles in corporate social responsibility: The CSR-HRM co-creation model. Business Ethics: A European Review, 24(2), 125-143.

Kirby, E., \& Krone, K. (2002). "The policy exists but you can't really use it": Communication and the structuration of work-family policies. Journal of Applied Communication Research, 30(1), 50-77.

Kossek, E. E., \& Van Dyne, L. (2008). Face time matters: A cross-level model of how work-life flexibility influences work performance of individuals and groups. In K. Korabik, D. S. Lero, \& D. L. Whitehead (Eds.), Handbook of work-family integration: Research theory and best practices (pp. 305-330). New York: Elsevier.

Kossek, E. E., Lewis, S., \& Hammer, L. B. (2010). Work-life initiatives and organizational change: Overcoming mixed messages to move from the margin to the mainstream. Human Relations, 63(1), 3-19.

Kossek, E. E., Hammer, L. B., Kelly, E. L., \& Moen, P. (2014). Designing work, family and health organizational change initiatives. Organizational Dynamics, 43(1), 53-63.
Lewis, S., Anderson, D., Lyonette, C., Payne, N., \& Wood, S. (2017). Public sector austerity cuts in Britain and the changing discourse of work-life balance. Work, Employment and Society, 31(4), 586-604.

Li, A., Bagger, J., \& Cropanzano, R. (2017). The impact of stereotypes and supervisor perceptions of employee work-family conflict on job performance ratings. Human Relations, 70(1), 119-145.

Lindloff, T. R., \& Taylor, B. C. (2002). Qualitative communication research methods (2nd ed.). Thousand Oaks, CA: SAGE.

Macke, J., \& Genari, D. (2019). Systematic literature review on sustainable human resource management. Journal of Cleaner Production, 208, 806-815.

Mele, D. (1989). Organization of work in the company and family rights of the employees. Journal of Business Ethics, 8(8), 647-655.

Mescher, S., Benschop, Y., \& Doorewaard, H. (2010). Representations of work-life balance support. Human Relations, 63(1), 21-39.

Moi, T. (1999). What is a woman? Sex, gender, and the body in feminist theory. What is a Woman (pp. 3-121). Oxford: Oxford University Press.

Nie, D., Lämsä, A.-M., \& Pučètaitè, R. (2018). Effects of responsible human resource management practices on female employees' turnover intentions. Business Ethics: A European Review, 27(1), 29-41.

Nyberg, D., \& Wrigth, C. (2013). Corporate corruption of the environment: Sustainability as a process of compromise. The British Journal of Sociology, 64(3), 405-424.

Pache, A. C., \& Santos, F. (2010). When worlds collide: The internal dynamics of organizational responses to conflicting institutional demands. Academy of Management Review, 35(3), 455-476.

Parker, I. (1992). Discourse dynamics: Critical analysis for social and individual psychology. London: Routledge.

Patton, M. Q. (2002). Qualitative research and evaluation methods (3rd ed.). Thousand Oaks, CA: SAGE.

Peper, B., den Dulk, L., ČernigojSadar, N., Lewis, S., Smithson, J., \& van Doorne-Huiskes, A. (2014). Capabilities for worklife balance: Managerial attitudes and employer practices in the Dutch, British, and Slovenian banking sector. In B. Hobson (Ed.), Worklife balance. The agency and capabilities gap (pp. 206-237). Oxford: Oxford University Press.

Perry-Smith, J. E., \& Blum, T. C. (2000). Work-family human resource bundles and perceived organizational performance. Academy of Management Journal, 43(6), 1107-1117.

Phillips, N., \& Hardy, C. (2002). Discourse analysis: Investigating processes of social construction. Thousand Oaks, CA: SAGE.

Phillips, N., Lawrence, T. B., \& Hardy, C. (2004). Discourse and institutions. Academy of Management Review, 29(4), 635-652.

Phillips, N., \& Malhotra, N. (2008). Taking social construction seriously: Extending the discursive approach in institutional theory. In R. Greenwood, M. Oliver, R. Suddaby, \& K. Sahlin (Eds.), The SAGE handbook of organizational institutionalism (pp. 702-721). London: SAGE Publications Ltd.

Pietiläinen, M. (Ed.). (2013). Työ, talous ja tasa-arvo. Helsinki: Statistic Finland.

Preuss, L., Haunschild, A., \& Matten, D. (2009). The rise of CSR: Implications for HRM and employee representation. The International Journal of Human Resource Management, 20(4), 953-973.

Putnam, L., \& Fairhurst, G. (2001). Discourse analysis in organizations: Issues and concerns. In F. M. Jablin \& L. Putnam (Eds.), The new handbook of organizational communication: Advances in theory, research and methods (pp. 235-268). Newbury park, CA: SAGE.

Putnam, L. L., Myers, K. K., \& Gailliard, B. M. (2014). Examining the tensions in workplace flexibility and exploring options for new directions. Human Relations, 67(4), 413-440. 
Pyöriä, P. (Ed.). (2012). Työhyvinvointi ja organisaation menestys. Tampere: Vastapaino.

Ross, J. P., Intindola, M. L., \& Boje, D. M. (2017). It was the best of times; it was the worst of times: The expiration of work-life balance. Journal of Management Inquiry, 26(2), 202-215.

Russo, M., Buonocore, F., Carmeli, A., \& Guo, L. (2015). When family supportive supervisors meet employees' need for caring: Implications for work-family enrichment and thriving. Journal of Management, 44(4), 1678-1702.

Schleutker, E. (2013). Väestön ikääntyminen ja hyvinvointivaltio. Mitä vaihtoehtoja meillä on? Yhteiskuntapolitiikka, 78(4), 425-436.

Shen, J., \& Benson, J. (2016). When CSR is a social norm: How socially responsible human resource management affects employee work behavior. Journal of Management, 42(6), 1723-1746.

Shockley, K. M., Douek, J., Smith, C. R., Peter, P. Y., Dumani, S., \& French, K. A. (2017). Cross-cultural work and family research: A review of the literature. Journal of Vocational Behavior, 101, $1-20$.

Statistics Finland. (2018). Population projection 2018-2070. Helsinki: Statistics Finland.

Sterponi, L. A. (2003). Account episodes in family discourse: The making of morality in everyday interaction. Discourse Studies, 5(1), 79-100.

Thompson, C. A., Beauvais, L. L., \& Lyness, K. S. (1999). When work-family benefits are not enough: The influence of workfamily culture on benefit utilization, organizational attachment, and work-family conflict. Journal of Vocational Behavior, 54(3), 392-415.

Turner, M. R., McIntosh, T., Reid, S. W., \& Buckley, M. R. (2019). Corporate implementation of socially controversial CSR initiatives: Implications for human resource management. Human Resource Management Review, 29(1), 125-136.
Van Dijk, T. A. (1993). Principles of critical discourse analysis. Discourse and society, 4(2), 249-283.

Voegtlin, C., \& Greenwood, M. (2016). Corporate social responsibility and human resource management: A systematic review and conceptual analysis. Human Resource Management Review, 26(3), 181-197.

Wharton, A. S., Chivers, S., \& Blair-Loy, M. (2008). Use of formal and informal work-family policies on the digital assembly line. Work and Occupations, 35(3), 327-350.

Wodak, R. (2011). Complex texts: Analysing, understanding, explaining and interpreting meanings. Discourse Studies, 13(5), 623-633.

Wood, L. A., \& Kroger, R. O. (2000). Doing discourse analysis. Thousand Oaks: Sage.

Wu, L., Su, R., \& Kossek, E. E. (2016). How important are informal work-family support? A meta-analytic path analysis of supervisor work-family support and employee outcomes. Closing the Gender Gap: Advancing Leadership and Organizations, 1(2), 2.

Zhang, S., \& Tu, Y. (2016). Cross-domain effects of ethical leadership on employee family and life satisfaction: The moderating role of family-supportive supervisor behaviors. Journal of Business Ethics, 152, 1085-1097.

Zuba, M., \& Schneider, U. (2013). What helps working informal caregivers? The role of workplace characteristics in balancing work and adult-care responsibilities. Journal of Family and Economic Issues, 34(4), 460-469.

Publisher's Note Springer Nature remains neutral with regard to jurisdictional claims in published maps and institutional affiliations. 